\title{
21. CAREER GUIDANCE FOR REFUGEES IN A NORDIC CONTEXT
}

\author{
The Need to Emphasise a More Collective Approach
}

\begin{abstract}
This chapter will address the need for a more collective approach to the career counselling of refugees and immigrants arriving in the Nordic countries. In order to meet their needs, we must define the concept and purpose of career guidance in broader ways. Picture-based group guidance seems to be particularly relevant for refugees with limited educational backgrounds. Common career guidance sessions for couples generally seems to work really well. In a Nordic context we must be particularly aware that family relations play a central role in most refugees' establishment of a new life in our societies. This might challenge the typical Nordic notion of integration as consensus and sameness.
\end{abstract}

\section{INTRODUCTION}

In 2004 Norway established a new statutory arrangement called the Introduction Programme based upon the Introduction Act (2003, pp. 241-242). The main goal of the programme was to strengthen refugees' opportunities to take part in the Norwegian work place and to be economically self-sufficient.

Career guidance given as early as possible after arriving in a new country offers refugees and migrants the opportunity to map their competence and skills, decide what education and training opportunities to take up and consider how these skills can be used in the workplace (NOU 2016:7, 2016, p. 191). The opportunity to receive work-related career guidance can hasten refugees and migrants integration into Norwegian society and help them to avoid social exclusion (NOU 2016:7, 2016).

Refugees and other immigrants with non-western backgrounds generally have a lower level of education and participation in the workforce (Statistics Norway, 2018). A significant number of the women refugees show inconsistent participation in the Introduction Programme and consequently make slower progress in learning the Norwegian language (Djuve, Kavli, Sterri, \& Bråten, 2017). For young men with little or no educational background, statistics show that the rate of those who enter the workplace or education is around $61 \%$. For women of the same age group, 
this number shrinks to $27 \%$ (Djuve et al., 2017). These numbers suggest that the Introduction Programme does not work as intended for those with limited formal educational backgrounds.

\section{THE INTEGRATION RECEPTION CENTRE IN OSLO}

In 2015 over 31,000 refugees arrived in Norway, three times as many as in the preceding years (Norwegian Directorate of Immigration, 2014). This was mainly a result of the war in Syria and the increasing number of people fleeing from African countries due to conflicts, poverty, and climate change. Over 15,000 of the refugees came during October and November. The Norwegian reception system was poorly prepared for this significant increase in asylum seekers and almost collapsed. Many temporary reception camps were set up and five new integration reception centres were established in 2016. The centres were based upon a new model of a full-time qualifications programme which aimed to assist the refugees to integrate better. The purpose was to achieve a more efficient transition towards the Introduction Programme through early intervention and cooperation between public agencies. Norwegian courses, mapping of skills, career guidance, and improving refugees and migrants' knowledge of Norwegian society were emphasised. The project was led by Skills Norway on behalf of the Ministry of Justice and Public Security. The regional career centres in Norway were assigned to develop and deliver career guidance for the refugees.

One of these new reception centres was established in Oslo and it was my responsibility to coordinate and develop career guidance for the refugees in cooperation with different public agencies such as the Education Authority and the Norwegian Labour and Welfare Administration. The Oslo Integration Reception centre accommodated 150 people. The majority of residents came from smaller towns or villages in Syria and Eritrea and had mostly worked as farmers or unskilled manual workers. The majority of the women had never had any paid work. It was soon identified that many of those who arrived had little or no educational background. Many were unable to read or write in their native language, and many did not have any digital competence either. Barely half of the newcomers had finished secondary education. Only around 5\% of the Eritreans had achieved any form of higher education, and many of these had spent a significant part of their lives in the military. Prior to the start of the project it was expected that a high percentage of the Syrian refugees would be highly educated. However, this was soon discovered not to be the case, with only $10-15 \%$ having received higher education. The majority of the refugees did not have any documentation on their school attendance.

In addition to educational issues, many had also suffered from traumas, both physical and psychological, which meant that they often had severe obstacles to overcome when it came to learning. We experienced a number of refugees who slept for long parts of the day whilst others could not sleep due to constant nightmares. 
Many were mostly concerned about how they were going to tackle the following day or the welfare of their children. Career guidance was not seen as a priority and many had never encountered the concept of 'career guidance' before. Consequently, we had to adjust and customise guidance and take a broad perspective on how we defined career guidance. We tried to be as flexible and helpful as we could. Often, in the first conversation which was more like a 'getting to know you' informal chat, we discovered several challenges which had to be dealt with. At times a part of each session was used to discuss the refugee's frustration and the practical difficulties facing them: lack of sleep, worries for the Norwegian child welfare authorities, worries regarding the Norwegian Directorate of Immigration (UDI), the ability to live with others in the reception centre and its facilities, as well as a complete lack of private life.

Integration has become a powerful emic term attributed with particular cultural, social, and political meaning denoting what it takes for immigrants, refugees and their descendants, to become a proper member of a given society (Olwig, 2010, p. 187). It is at this point important to be aware of the common Nordic notion of what integration means. Scandinavian welfare societies are predicated on notions of sameness and consensus, and the incorporation of immigrants and refugees is seen as a responsibility of the welfare state. (Olwig, 2010, p. 185). But the efforts of turning immigrants and refugees into 'good citizens' might fail as we try to shape these population groups - socially, culturally, physically and psychologically - according to Scandinavian norms (Olwig, 2010).

Integration programmes for refugees have a propensity to treat people in terms of categories that can be dealt with in the bureaucratic system (Eastmond, 2011, p. 281). The tendency to define refugees as dependent and a burden on receiving countries has also been well documented in international research on southern countries (Eastmond, 2011). Refugees within the welfare institutions of northern states, as clients, may be perceived in similar terms. Clients in welfare bureaucracies tend to be seen as incomplete persons with diminished agency (Eastmond, 2011, p. 282). We should be highly aware of this in the work with career guidance for refugees and immigrants.

\section{The Use of Interpreters in Career Guidance}

There was always a professional interpreter present during all meetings we had with the refugees. However, using an interpreter in career guidance is a skill that needs to be learned. Face-to-face interpretation is the most efficient way of interpretation in a counselling session. When using an interpreter, it is important to speak in clear and short sentences, so that the interpreter can translate what is needed before starting a new sentence. The counsellor should not say too much before receiving an answer from the counselee. When working with an interpreter, it's important that we engage in what is known as active listening. Listening can be broken down into three levels: 
(1) inner listening; (2) focused listening; and (3) non-verbal listening (Gjerde, 2010, pp. 121-123).

Listening on level 2 and level 3 is more challenging when using an interpreter. It can also be quite time consuming and therefore requires that more time is allocated for career guidance sessions. Not all aspects of active listening can be easily used, such as halting the conversation or repeating a specific part of a question. Making and maintaining eye contact with the counselee is also an important part of nonverbal listening, but it is not always easy when an interpreter is involved. Nonverbal listening is an intuitive form of listening which it is difficult to manage when working with an interpreter. When you are listening at level 3 in an interpreted conversation, there will be moments of body positioning, voice control, or posture, which cannot be fully conveyed through the interpretation and yet must be attended to by the career counsellor.

It is also important to communicate directly to the counselee and not to the interpreter. We experienced it as quite usual for the counselees to approach the interpreter directly rather than the career counsellor, and we found this a major challenge in all situations including an interpreter. Other times we experienced that neutral interpretation was not always in place either, as both the interpreter and the counselee could come from different tribes or different sides of a conflict. We had to be careful about which interpreters we used when counselling Syrian refugees as some identified strongly with conservative political parties while others supported Bashar al-Assad. Regional dialects and accents also made things harder than first envisaged. For example, the Kurdish language is characterised by several regional dialects that have to be taken into consideration when using an interpreter as there is no guarantee that all interpreters can understand local dialects.

The challenges facing multi-cultural communication and the use of interpreters was also addressed in a Finnish research project (Launikari, 2005) which considered the interpreter's role as a facilitator in intercultural communication. This research project asked 20 Finnish career counsellors about their experiences in the use of interpreters in career guidance with immigrants and their experience was very similar to ours. According to the respondents, the most positive aspect of working with an interpreter is that it helps focus on the essential and that it carries information over language and cultural barriers without changing the content. Also, words and meanings are often not interchangeable between languages. Many of the Finnish respondents, like we did, often experienced difficulty in reading the non-verbal communication of the client, but talking to the interpreter about the communication after the interpretation was said to be very eye-opening (Launikari, 2005, p. 163). It feels safer to work with an interpreter who you have worked with previously. One problem, however, can actually be finding the best interpreters when you need them. This was a problem that they also experienced in Finland (Launikari, 2005, p. 163). 


\section{Changing Our Approach}

When new refugees arrived, we mapped their educational background, level of language knowledge, and predicted progression in terms of learning Norwegian, based on a series of factors. They were then placed on an appropriate Norwegian course. Many did not have any relevant forms of training or education from their home country, and those were placed on track 1 or slow progression of track 2 . Track 1 indicates that the person has little or no formal educational background, the reading and writing skills are low and the progression is generally slow. Track 2 indicates that the person has some educational background and is able to use written language as a tool for learning. Some have little or no experience with the Latin alphabet which makes progression slow.

Since this group of refugees was so large we had to concentrate on customising the career guidance according to their needs. When working with career guidance in a multicultural context one must be cognisant of the importance of having intercultural competence. It is important to be aware of who you are in terms of meeting a counselee who has a different cultural background:

Most published methods of guidance and counselling emerged in an environment where of the counsellor and the counselee belongs to a similar cultural background. However, today there is a higher likelihood of counsellor and counselee coming from different cultural and religious backgrounds, each influenced and guided by their own beliefs and orientation to work. The methods of guidance that emerges from western theories are often a response to needs expressed from within these cultures. (Arulmani 2011)

This was something that we constantly had to be aware of in order to avoid being trapped by our own cultural expectations and norms. This requires a lot of concentration, self-awareness, courage and patience from the career counsellor. A major challenge was that the context and the system we worked within were funded on the typically western mainstream assumptions of what career guidance should be and what should be the purpose of it. As an example, the refugees were expected to use computers to register their educational background, previous work experience, and their chosen career goal. The information would then be used to prepare the career counselling sessions. However, many of those who came did not have much, if any, experience with digital technologies and the majority were dependent on help to register the information. Some could not even read in their native language. Many felt that they were offered far too many alternatives on the answers and they were not sure which of those best suited their situation. The information could therefore only be used as a rough sorting mechanism in conjunction with career guidance. Often, we did not use this information at all because so many things came out wrong. This shows how a lack of intercultural competence among those who develop new concepts and programmes may affect the usefulness of the product they make. 
Researchers concerned with the cultural relevance of interventions (Griffin \& Miller, 2007; Reese \& Vera, 2007) have pointed out that the development of programmes must be based upon a deep knowledge of ways of life and world views of the community for which the programme is being developed (Arulmani, 2011). Scandinavian research shows that various efforts at treating refugees as individuals that need to be immersed in Scandinavian culture and society instead of as members of supportive family groups may have the opposite result of hindering rather than facilitating the sort of social incorporation that was intended (Olwig, 2010, p. 192).

\section{Group Guidance}

At first, we focused mainly on individual career guidance sessions. These sessions became popular among those with higher education and those with a number of years of work experience, but seemed not to work that well for the unskilled newcomers. Few refugees actually understood our western founded concept of career guidance: they spoke very little and seemed disinterested in what we could offer. They would shrug their shoulders when asked what type of resources they had or answer 'I don't know' when asked simple follow-up questions. Western values such as individualism and autonomy, the centrality of the work role, affluence, and the linearity or progressive nature of career development, may have limited utility for counselees whose worldview is more aligned with collectivistic values (Arthur \& Popadiuk, 2010). Typically, Nordic norms such as sameness and consensus were not understood the same way by the majority of the refugees. After experiencing several difficulties, we decided to try out group guidance.

Facilitating a group career guidance session that also included an interpreter was new to us. We soon experienced that we would have to be generous with time and that the groups should be relatively small with a maximum of six. We generally used pictures to encourage enthusiasm for the process and build understanding of what was going on. Our aim was to develop participants career competencies through career learning.

The participants were asked to sit down around a table, while the counsellor and the interpreter would move around as needed. We started by introducing ourselves and explained the premise of the session, what was going to happen, and the purpose of it. We agreed to a set of rules of play so everyone knew what would happen and what their role would be. The conversation was facilitated by the counsellor and progressed in systematic rounds so that everyone was committed to participate.

We began with a round where the participants should say something about their most positive characteristic, here even the interpreter and the counsellor had to contribute. Many felt it was quite embarrassing to talk about what they actually could do rather than what they could not. Sometimes we asked them to draw their favourite animals and then tell why they liked this animal and what characteristics it possessed. Many chose to draw an animal that had the same characteristics as themselves. We 
let those who began to talk contribute and let the conversation wander freely. The interpreter had quite a job sometimes to make sure that the participants did not cut each other off mid-sentence.

After this, we worked with picture cards. The cards we used showed pictures of people in various contexts and situations. They were not only linked to specific job situations and professional settings, but showed people working, studying, travelling, performing hobbies and other interests. Some pictures focused more on the individual and specific jobs, some focused more on relations, and some were pictures that could be interpreted in many ways. I will now describe one of the many possible ways to work with picture cards.

Each person should pick a number of cards that they liked. For this we gave them around 20 minutes and the interpreter tried to give a running commentary to what was discussed among the participants. Then we went through which cards had been chosen, one at a time. The counsellor could ask 'Why did you choose this card?' 'What do you like about it?' 'Can you tell more about why you like it?' Here we also used the opportunity to talk about which cards they didn't like, which often became interesting because other participants in the group had a different perception of the same picture.

The picture cards were colour coded using John Holland's interest categories (Højdal \& Poulsen, 2012, p. 89). We looked at each card and explained what it meant using the RIASEC hexagon. Most of those involved found it to be quite interesting, and it led to discussions and comments from most of the participants. Finally, each person made their own RIASEC code based on the pictures they had chosen. Again, this led to a great deal of discussion and many felt that what they had chosen actually suited what they thought of themselves. The counsellor facilitating this exercise emphasised that the cards are not a tool which gives an absolute answer to what should be the right job or career for a certain person. Rather it can give a good indication that they can use as a starting point for their career exploration.

In the group sessions, we had the opportunity to talk about the trades and attributes that are often matched together in Norway. We would also look at a series of job advertisements to show that different companies may look for people with different characteristics and skills. This was relevant for many and emphasised the exercise that we had previously taken with the RIASEC cards. Many of the refugees pointed out this as extremely relevant for them later on, and many also wanted more counselling.

In establishing the groups, it was important to consider the educational background of the refugees. Mixing people who could not read and write with those with a university education led to a lack of enthusiasm and participation. We also divided the groups between gender when it seemed appropriate: for some of the refugees, their views about gender could limit their opportunity to participate. This created a dilemma since in the long run everyone needed to understand and respect that in Norway, both genders are seen as equal on all levels. Men and women participate 
in social and professional settings together as well as at the workplace. However, it seemed both counterproductive and unethical to force people into mixed gender groups. As a possible solution to this problem we chose to bring in the gender aspect as a part of the discussion in these sessions. We chose this approach in order to open up for further reflections about this important issue. Norm criticism can be an appropriate method to address these issues (Wikstrand, 2019). Wikstrand describes five aspects of norm criticism in career guidance work: challenge what is taken for granted; see yourself and your relations; create awareness of what has been made a norm; work reflexively; and change your practice (Wikstrand, 2019, p. 222).

\section{Career Guidance Sessions for Couples}

The refugees who arrived with families had a completely different lifestyle than those who were single. Challenges often arose when a counselee who was married took part in either group or individual career guidance sessions. Their partner often could not understand why he or she could not be present in the session too. We also experienced that many of the women did not show up for their appointments, preferring to stay at home at the reception centre. Many had small babies and were at risk of not participating in the programme and failing to learn Norwegian.

In a Nordic context, married couples are usually seen as giving each other "friendly advice" and both have as much authority as the other person. They can discuss experiences openly and it can also be ok to disagree with one another. For some of those who come from a different culture, it cannot be seen as a certainty that they discuss things openly with their partner. This can, as an example, apply to the content of a career guidance session and plans that have been made in through the counselling. In some cultures, such as the Syrian, the families often have a very significant influence on what occupations are pursued by members of the family (Sultana \& Watts, 2008). The individualistic approach might be non-relevant and non-understandable for counselees from collectivistic societies (Arulmani, 2012). The collective identity is embedded so deeply that it is impossible to separate it from the individual. The typical western way of sorting things out individually, and making individual plans, might not lead to anything but frustrations, misunderstandings, and a lack of motivation among collectivistic oriented persons.

As a more collective approach, I decided to try out common career guidance for couples. I began to think about how this method could differ from other approaches. What should we talk about and how should I prepare? What should be the goal? Would the refugees think that some questions were too direct or personal? Was the method and approach ethically good? What should happen if problems occurred underway? The sessions were planned for approximately two hours with a small break built in. The refugees decided how they wanted to talk and what they wanted to talk about, and we therefore did not follow any specific path. If needed, the sessions would take place in a larger location where the couples could bring along babies and 
small children. For some of the families this was a necessary premise as they had their children with them all the time. The necessity of choosing the right location in order to succeed with career guidance is also described in detail by Thomsen (2012).

Introductory questions could emphasise their current personal situation, their family situation, the progression of their asylum application and the Norwegian course. Other topics could be the significant differences between Syrian and Norwegian family life. Here, intercultural competence could be brought in, both as an implicit part of the conversation, and also as an explicit topic based on professional knowledge. This could be about individualistic oriented culture versus collectivistic cultures, patriarchal societies in contrast to more flat and open societies, and the different perception of time in monochrome and polychrome cultures (Geert, Hofstede, \& Minkov, 2010). Typical challenges and misunderstandings around these topics could then be brought up and discussed. Norwegian maternity rights and the benefits and disadvantages when it comes to this way of organising family life should also be discussed as this is a very specific Nordic phenomenon. Family planning could also be a subject, although I had to be very careful about when it seemed appropriate to bring this into the discussion. Religious aspects of life were only discussed if the couple brought this up as an important issue, even though religion extensively affects people's lives and careers and should be emphasised since it often represents the foundation of their lives.

The Norwegian educational system was also a very important topic as it differs a lot from schooling systems in the refugees' home countries. The Syrian educational system is rigid with out-dated curricula, no tailoring for specific learning needs, rote learning instead of higher order cognitive skills and not much development of labour market skills (Diab \& Barakat, 2017, p. 241).

We also used some time discussing how old people live and how they are taken care of in the Norwegian welfare system. This could bring the conversation to the importance of the welfare system and the importance of contributing to its maintenance. Why is it important to pay tax? What happens if more people become dependent on social benefits? What are the consequences when women stay at home instead of working?

All of the couples who participated seemed highly motivated ahead of the sessions and no one arrived late for their appointments, as often was the case elsewhere in the project. The discussions in general seemed to focus on how they could have a future as a family in Norway. I used a lot of time to discuss the impact education and jobs have on most families in Norway. The men generally found it extremely difficult not working, many felt they had lost both their status and their breadwinners' role in the family. The women handled the situation far better, perceiving "being at home" as a more normal situation. Sometimes it was necessary to bring up the importance of two people earning wages in Norway, for many of the couples this was not anything they ever had to consider before they arrived in Norway. Most of the women expressed that they wanted to have a job and receive education. The men seemed to understand 
the difficulty of having just one income in the family and seemed positive about their spouses getting paid work.

What surprised me a lot was how happy a number of the men were with the counselling. They seemed to feel both happier and safer in the common guidance setting than in an individual guidance setting. They were also more open together with their partners than without them. The women were typically less active in the beginning of the discussions. They seemed surprised that the counsellor took such a direct and informal tone with them, but they became more active as the conversation progressed, and seemed very happy that they 'were seen'. None gave any impression that they felt that the counsellor had been too personal or too direct.

\section{Feedback}

The career guidance performed in the Integration Reception Centres is still under development and has not been systematically evaluated yet. However, if we look at the feedback from the refugees, we can see that they expressed that the guidance made a positive contribution in their lives. We systematically asked them if they had any suggestions for changes or improvements. If something came up we tried to do things in a different way. Many have also been in touch after they got settled to tell us how lifechanging the career guidance has been for them.

The majority of those that we met felt that they had been seen and therefor felt more motivated in terms of learning. The concept of making the refugees understand what was realistic was often difficult for the counsellors, but many were thankful for what we helped them with even though it felt that the information changed their dreams at first. Many had to consider working in a different occupation than they did back in their home country due to a very different job market. They told us later on that they had begun to think differently about themselves, their skills and their personal characteristics and their cultural background. Many pointed out that particularly the group sessions and the family sessions had motivated them a lot, and some also asked for further career counselling.

It seems clear that many couples and families would prefer and benefit more from having one common family career development plan rather than one for each of them - so perhaps we should look to develop a more family-oriented system based on this approach.

The presence of the career counsellors was important as the residents of the centre did not have many other sources of support and opportunities to share their personal stories with. Being together in informal settings, taking part in arrangements, birthday parties, being able to give advice in other places than in an office, and being able to give advice there and then were highly appreciated. This way of working with career guidance in communities is also carefully described by Thomsen (2012). 


\section{CAREER GUIDANCE AND SOCIAL JUSTICE}

In recent years the international career guidance discourse has been increasingly concerned about the lack of emphasis on social justice in career guidance. The critics claim career guidance can easily serve as a mechanism for responsibilisation and cooption and that the interest of individuals and the state are not always aligned (Hooley, Sultana, \& Thomsen, 2018). How far is it legitimate to seek to channel individuals towards particular occupations on the ground that this is to benefit the nation? And to lead individuals towards particular ways to live their lives, ways that do not always lead to health and happiness (Hooley et al., 2018, p. 18; Sultana, 2017, p. 10).

Being adaptable, employable, and flexible are often described as important 'metaskills' in official reports addressing future needs for competence (e.g. NOU 2018:2, 2018; NOU 2019:2, 2019). In conjunction several governmental reports address how to make integration more efficient (e.g. Ministry of Justice and Public Security, 2016). We need to be highly aware of the mechanisms underpinning such reports to avoid oppression and support growth through career counselling of immigrants and refugees.

One problem arising from the welfare societies' integration programmes concerns their insistence on the need to learn the local language, social norms, and cultural values and traditions before seeking employment in the receiving societies (Olwig, 2010, p. 186). Their strong focus on local socio-cultural skills that needs to be mastered before it is possible to manage in the society has had the unfortunate consequence that they have tended to treat refugees and immigrants in terms of what they are lacking, rather what they can offer (Olwig, 2010, p. 186). A person who is not selfsupportive at the end of the Introduction Programme will remain the responsibility of social services, as the introductory grant converts into a welfare cheque (Eastmond, 2011). This is an extremely unfortunate situation, both for the welfare states and the newcomers, and must be taken more seriously into consideration.

Before the Integration reception centres got established, refugees did not get in contact with employers or work-places before they started the Introduction Programme. Many lived in various reception camps for years before they got their residence permit and finally got in contact with the Norwegian society. In the Integration Reception Centre in Oslo we had a major focus on breaking down barriers towards refugees' engagement with work-places. Employers, volunteers, and staff from local universities were invited in and many refugees connected closely with them. Some companies and employers made contact even if they were not invited in. Many of the refugees participated in different types of work training before they could make themselves understood in Norwegian. This could be challenging for both the employers and the employees, but this opportunity to contribute and be part of something quickly became very popular among the refugees. Being present in workplaces also made a big impact on their oral Norwegian skills. Some made Norwegian friends and a network that seemed to be very important, not least after 
moving out of the reception centre. This perspective on early integration should be taken into consideration by all the Nordic countries. To treat people as they are and as a resource, is paramount to succeed with integration even if it is hard to let our welfare-oriented notion of 'proper' integration go.

Career counsellors should consider systemic and social influences on career concerns and to select interventions that go beyond helping counselees cope and adapt to oppressive social conditions that contributed to their work and career barriers in the first place (Arthur \& Collins, 2011). Krumboltz and Worthington (1999) suggest that career counsellors should show the counselees how they can expand their interests and capacities and not merely match people to a particular career on the basics of their existing characteristics. To help people define new targets for learning should be more emphasised among career counsellors working with refugees and immigrants. The counsellor could e.g. ask their counselees: 'Are there some skills that you would like to improve? How could you develop some new skills?' (Krumboltz \& Worthington, 1999, p. 315).

A new report addressing social inequality in Norway shows an increase in social inequality even though Norway remains as the European country with the lowest level of inequality (Hoen, Markussen, \& Røed, 2018). One of the reasons for increasing inequality is that there are not enough jobs for unskilled workers. Unskilled immigrants and unskilled ethnic Norwegians could be perceived as rivals for these jobs. Immigrants generally earn less than ethnic Norwegians (Hoen et al., 2018). This can lead to more unemployment and poverty amongst low skilled ethnic Norwegian jobseekers. At the same time rich people benefit even more from cheap labour (Hoen et al., 2018). This development in Norway also needs to be seen in conjunction with a general increase in social inequality in the rest of the world.

\section{CONCLUSION}

When working with refugees and immigrants career guidance should be seen as a flexible concept that allows for the exploration of flexible modes of delivery. Having intercultural competence is an absolute necessity for the career counsellor to deliver career guidance of high quality. The career counsellor should emphasise to challenge the system he or she is working within in order to facilitate an increased awareness regarding social inequality and social justice. Even if Norway has the lowest level of social inequality in Europe, the problem with unemployment and poverty is increasing.

Refugees could benefit a lot from being taught what intercultural competence could mean to them and this could contribute to more appropriate communication in the cultural context of their Nordic host country. But we also have to consider that the collectivistic-patriarchal conception of life is extremely deeply rooted in many individuals, and that trying to change this might not be possible nor ethically good.

A respectful and impartial foundation in career guidance is needed to build up a trustful relationship between the counsellor and the counselees. Genuine interest, 
being able to listen properly and giving advice there and then, is paramount to be able to do a good job as a career counsellor for newcomers.

Picture-based group guidance became a preferred counselling method for those with little or no education. The use of interpreters is challenging, but a necessity in this context. Anchoring of career plans within the family seems to be of great importance for those coming from collectivistic societies. Common guidance for couples worked surprisingly well, and this should be recognised and developed further. We are probably on the right track when we emphasise both early intervention and customised career guidance that is tailored to fit each cultural group and each individual.

As highlighted in the Norwegian Official Report NOU 2016:7 (2016), career guidance should definitely be used as a method to achieve greater integration in Norway. But we need to be constantly aware of the political context which surrounds us to avoid reproducing negative cultural and social patterns through career counselling.

In March 2018 the Integration Reception Centre in Oslo got shut down due to few arrivals. The other reception centres in Norway are still in operation, however, the refugees arriving currently are a different group from those arriving between 2015 and 2017. In this context it is important to explain that the methods that were developed in Oslo mainly got developed for, and in cooperation with, a specific group of refugees, namely Eritreans and Syrians with very little formal education and a collectivistic life approach.

\section{REFERENCES}

Arthur, N., \& Collins, S. (2011). Infusing culture in career counseling. Journal of Employment Counseling, 48, 147-149. doi:10.1002/j.2161-1920.2011.tb01098.x

Arthur, N., \& Popadiuk, N. (2010). A cultural formulation approach to career counseling with international students. Journal of Career Development, 37, 423-440. doi:10.1177/0894845309345845

Arulmani, G. (2011). Striking the right note: The cultural preparedness approach to developing resonant career guidance programmes. International Journal for Educational and Vocational Guidance, 11(2), 79-93. doi:10.1007/s10775-011-9199-y

Arulmani, G. (2012). The Cultural preparedness approach to working with career beliefs. Indian Journal of Career and Livelihood Planning (IACLP), 1, 44- 48.

Diab, B., \& Barakat, N. (2017). Career services in Syrian higher education. In R. G. Sultana (Ed.), Career guidance and livelihood planning across the Mediterranean (pp. 239-254). Rotterdam, The Netherlands: Sense Publishers.

Djuve, A. B., Kavli, H. C., Sterri, E. B., \& Bråten, B. (2017). Introduksjonsprogram og norskopplcering. Hva virker-for hvem? [Introductory programme and Norwegian language training. What works - for whom?]. Fafo-report 2017:31. Oslo: Fafo.

Eastmond, M. (2011). Egalitarian ambitions, constructions of difference: The paradoxes of refugee integration in Sweden. Journal of Ethnic and Migration Studies, 37(2), 277-295.

Geert, H., Hofstede, G. J., \& Minkov, M. (2010). Cultures and organizations. New York, NY: McGrawHill.

Gjerde, S. (2010). Coaching. Hva - hvorfor - hvordan? [Coaching. What - why - how?] (2nd ed.). Bergen, Norway: Fagbokforlaget. 
Griffin, J. P., \& Miller, E. (2007). A research practioner's perspectiveon culturally relevant prevention: Scientific and practical considerations for community-based programs. The Councelling Psychologist, 35, 850-859. doi:10.1177/0011000007307999

Hoen, M. F., Markussen, S., \& Røed, K. (2018). Immigration and social mobility. IZA Discussion Paper No. 11904. Retrieved from http://ftp.iza.org/dp11904.pdf

Højdal, L., \& Poulsen, L. (2012). Karrierevalg. Teorier om valg og valgprocesser [Career choice: Theories on choice and processes of choice]. København, Denmark: Schultz.

Hooley, T., Sultana, R., \& Thomsen, R. (2018). The neoliberal challenge to career guidance - Mobilising research, policy and practice around social justice. In T. Hooley, R. Sultana, \& R. Thomsen (Eds.), Career guidance for social justice (pp. 1-27). New York, NY: Routledge.

Introduction Act. (2003). Lov om introduksjonsordning og norskopplcering for nyankomne innvandrere (Introduksjonsloven) [Act on an introductory programme and Norwegian language instruction for newly arrived immigrants]. (LOV-2003-07-04-80). Retrieved from https://lovdata.no/lov/2003-0704-80

Krumboltz, J. D., \& Worthington, R. L. (1999). The school-to-work transition from a learning theory perspective. Career Development Quarterly, 47, 312-325. doi:10.1002/j.2161-0045.1999.tb00740.x

Launikari, M. (2005). Intercultural communication as a challenge for counselling immigrants. In M. Launikari \& S. Puukari (Eds.), Multicultural guidance and counselling - Theoretical foundations and best practices in Europe (pp. 151-172). Jyväskylä, Finland: University of Jyväskylä.

Ministry of Justice and Public Security. (2016). Fra mottak til arbeidsliv - en effektiv integreringspolitikk [From reception centre to the labour market - An effective integration policy]. Meld. St. 30 (20152016).

Norges offentlige utredninger (NOU) 2016:7. (2016). Norge i omstilling - karriereveiledning for individ og samfunn [Career fuidance for individuals and society]. Oslo, Norway: Norwegian Government Security and Service Organisation.

Norges offentlige utredninger (NOU) 2018:2. (2018). The future's need for competence I [Fremtidige kompetansebehov I - Kunnskapsgrunnlaget]. Oslo, Norway: Norwegian Government Security and Service Organisation.

Norges offentlige utredninger (NOU) 2019:2. (2019). Fremtidige kompetansebehov II - Utfordringer for kompetansepolitikken [The future's need for competence II]. Oslo, Norway: Norwegian Government Security and Service Organisation.

Norwegian Directorate of Immigration. (2014). Asylsøknader etter statsborgerskap og år (2007-2014) [Asylum applications lodged in Norway by nationality and year (2007-2014)]. Retrieved from https://www.udi.no/statistikk-og-analyse/statistikk/asylsoknader-etter-statsborgerskap-ogar-2007-2014/

Olwig, K. F. (2010). 'Integration': Migrants and refugees between Scandinavian welfare societies and family relations. Journal of Ethnic and Migration Studies, 37(2), 179-196. doi:10.1080/136918 3 X.2010.521327

Reese, L. E., \& Vera, E. M. (2007). Culturally relevant prevention: The scientific and practical considerations for community-based programs. The Councelling Psychologist, 35, 763-778. doi:10.1177/0011000007304588

Statistics Norway. (2018, March 13). Employment among immigrants, register-based. Retrieved from https://www.ssb.no/en/arbeid-og-lonn/statistikker/innvregsys

Sultana, R. G. (2017). Anchoring career guidance in the Mediterranean? In R. G. Sultana (Ed.), Career guidance and livelihood planning across the Mediterranean: Challenging transitions in South Europe and the MENA region (pp. 3-18). Rotterdam, The Netherlands: Sense Publishers.

Sultana, R. G., \& Watts, A. G. (2008). Career guidance in the Middle East and North Africa. International Journal of Educational and Vocational Guidance, 8, 19-34. doi:10.1007/s10775-007-9133-5

Thomsen, R. (2012). Guidance in communities. Copenhagen, Denmark: Schultz.

Wikstrand, F. (2019). Norm criticism. In T. Hooley, R. Sultana, \& R. Thomsen (Eds.), Career guidance for emancipation (pp. 216-231). New York, NY: Routledge. 